\title{
LIABILITY PROBLEMS OF AIR CARGO CARRIAGE
}

\section{Charles S. Rhyne*}

Air transportation of cargo had its beginning at about the same time as did air transportation of passengers. On November I4, I9I9, the American Railway Express sponsored a cargo plane flight which was unsuccessful because of a forced landing; however, this unfortunate experiment was followed by successful operations of the Ford Motor Company in 1925 and the American Railway Express in $1927 .^{1}$ Further development in this field of aviation was stimulated by the transfer of the air mail service to carriers, and in the early I930's several major airlines took an active part in the transportation of property by air, but unfortunately found there was insufficient traffic to pay expenses. ${ }^{2}$ There was continued activity in this field of aviation, but it was not until the end of World War II that the transportation of air cargo consisted of anything except small express shipments. American Air Lines was a pioneer in providing extensive freight service, beginning on October 15,1944 , and in the next two years was followed by a majority of the other major airlines and several noncertificated cargo carriers. ${ }^{3}$ In 1946 the carriers carried an estimated fifty million ton miles, three times as much as was hauled during the six preceding years. ${ }^{4}$

From the very beginning of shipments of property by air the carriers have imposed a limitation on their liability. The Ludington Airlines and the General Air Express in the early I930's limited their liability to the declared value of shipments carried by them. 5 The American Railway Express, the only carrier maintaining continued operations in this field down through the years, in the operation of its express service in interstate commerce has transported goods on the Air Express Receipt, limiting its liability to the declared value of any shipment it accepts. ${ }^{6}$ This was followed by the United Airlines in filing its first tariffs on February I, I946.7 Shipments were accepted subject to a released valuation not exceeding $\$ 5^{\circ}$ for shipments of Ioo pounds or less, or 50 cents per pound for shipments in excess of roo pounds, with the shipper having the opportunity of declaring a value in excess of the above amounts and paying an additional ro cent charge for each \$roo or fraction thereof above the released value. This procedure was in turn adopted by the other carriers. $^{8}$

There is little statutory or case law on damage claims for injury in aircraft acci-

- Member of the District of Columbia bar. Chairman of the Aeronautical Law Committee of the American Bar Association.

1 Sorrell, Prospective Cargo Traffic, Prospects and Problems in Aviation (i945).

${ }^{2}$ Frederic and Lewis, History of Air Express, 12 J. ATR L. AND CoM. 203 (I944).

3 Torgerson, History of Air Freight Tariffs, 15 J. AIR L. AND CoM. 47 (1948).

- Drew and Passen, Air Cargo: A New Force in Marketing, 14 J. AIr L. AND Com. II (I947).

"Frederic and Lewis, supra note 2, at 210, 222.

-Anderson, Liability of Air Carriers, ${ }_{3} 3$ J. Arr L. ANd Com. 281 (1942).

7 Torgerson, stupra note 3 , at 50.

${ }^{B}$ lbid. 
dents to baggage or cargo. There is no federal legislation on the subject and Maryland has the only sțate statute. ${ }^{9}$ No court has passed upon the validity of the limitations contained in the Air Express Receipt, ${ }^{10}$ or on the validity of baggage regulations filed in air carrier tariffs under the Economic Regulations ${ }^{11}$ promulgated by the Civil Aeronautics Board pursuant to the Civil Aeronautics Act. ${ }^{12}$

Adequate insurance coverage is available to today's air cargo carrier, but it must be concerned with obtaining cargo insurance at rates which are reasonable to it and at the same time provide adequate coverage for the shipper's property. It is evident that the amount the carrier must pay for adequate insurance will directly affect the amount the shipper must pay for shipping his property, which in turn will ultimately affect the amount of property shipped by air. It must be recognized that it is to the advantage of the carrier, the shipper, and the public in general that transportation of property by air be extended to its fullest capabilities. This can only be done if the carriers offer reasonable shipping rates and at the same time assure the shipper a reasonable return if his property is lost or damaged.

It would seem that the problem of reasonable rates for insurance is closely related to the right of the carrier legally to limit its liability by publishing the limitation in the express receipt or in a tariff, for by so doing it can carry a lesser amount of insurance. In regard to the shipper any proper solution must be fair. He is at least entitled to the assurance of a return of the reasonable value of his property in case of loss or damage as well as being able to ship his property at reasonable rates and to know approximately his status in the situation. Really the main difficulty in this field of aviation is uncertainty.

Generally the first problem to be considered in determining the liability of a carrier is to ascertain whether the carrier is a common or private one. The chief test applied is whether or not the operator of the aircraft, either by express written or oral statements, or by his course of conduct, holds himself out to the public as willing to carry at a fixed rate all persons applying for transportation or all goods presented for carriage so long as his plane or planes will carry them. ${ }^{13}$ Different rules of liability apply to these two types of carriers. Private carriers are liable only if negligent while, in the absence of statutes, common carriers are held to be insurers of the safety of property entrusted to their care except for loss caused by acts of God,

${ }^{\circ}$ Md. Laws 1931, c. 403; 193I U. S. Av. R. 365. The Maryland statute, which applics only to interstate and foreign air commerce, requires a written declaration of the character and value of certain named articles at the time they are entrusted to an air carrier or the carricr is not liable as "carricr thereof in any form or manner." These articles include gold and other precious metais and goods. Air carriers are exempt from liability for damages caused by injury or loss of such articles caused by faults or errors in navigation, dangers of the air, acts of God or a public enemy, inherent defects of the thing carried, insufficiency of package, seizure under legal process, acts of the shipper, or acts done while attempting to save life or property.

${ }^{10}$ Charles S. Rhyne, Aviation Accident Law 105 (1947).

${ }^{11}$ Sce Sec. 2241 as amended.

${ }^{22} 52$ StAT. 992 (1938), 49 U. S. C. $\$ 483$ (1946).

${ }^{13}$ For a discussion with cases on the subject of aircraft operators as common or private carriers, sec Rhyse, op. cit. supra note ro, at $45-54$. 
the public enemy, public authority, or the shipper, or by the inherent nature of the goods. However, since the Economic Regulations of the Civil Aeronautics Act of $193^{14}$ apply only to common carriers, this article will consider only the problems of the common carrier of cargo by air.

Since it is the general rule that common carriers of goods are held liable for loss or damage of goods entrusted to their care, it would logically appear that common carriers of goods by airplanes are subject to the same general rules as other common carriers and that the courts will most certainly apply to the common carrier by air the same rules which the common law developed for the others. ${ }^{15}$

Courts in the United States have consistently held provisions limiting the liability of air carriers and other common carriers for damages arising from personal injuries to passengers invalid as contrary to public policy. ${ }^{16}$ These courts, however, have upheld such liability limitations when applicable to baggage or express if such provisions are reasonable and do not exempt the carrier from liability for its own negligence. $^{17}$ Also, the United States courts have held that provisions in the ticket providing that the company was not a common carrier are invalid. ${ }^{18}$ The Supreme Court of the United States has said:

Whether a transportation agency is a common carrier depends not upon its corporate character or declared purposes, but upon what it does. ${ }^{19}$

The Civil Aeronautics Act of $193^{8}$ requires the carriers to file tariffs ${ }^{20}$ with strict observance of those tariffs enforced upon the carriers ${ }^{21}$ and with any departure from them made a criminal offense. ${ }^{22}$ It is within these tariffs that the carriers' limitations of liability are found, and the problem arises now as to the effect of these filed tariffs on the contracts of carriage. Since there is no statutory or case law on this particular subject, it is necessary to determine how the problem has been handled in other fields and by analogy apply that to aviation.

Where the problem has come before the courts as to the rates charged by the carriers the courts have almost consistently held that the filed tariff is conclusive evidence of the contract of carriage. ${ }^{23}$ However, where the problem involves a rule

14 52 STAT. 977 (1938), 49 U. S. C. $\$ 40$ I (1946). See RHYNE, Federal, State and Local Jurisdiction Over Civil Aviation, ir Law and ConteMP. Prob. 459 (1946).

1"Godehn et al., Proposed Law of Air Flight, 8 J. AIr LAw 505, 530-539 (1937); Greer, The Civil Liability of an Aviator as Carrier of Goods and Passengers, I J. AIr LAW 24I, 244 (1930).

${ }^{16}$ Allison v. Standard Airlines, 1930 U. S. Av. R. 292 (U. S. D. C. Calif. 1930), affd, 67 F. 2d 668 , 1933 U. S. Av. R. 92 (C. C. A. 9th 1933); Curtiss-Wright Flying Service, Inc. v. Glose, I933 U. S. Av. R. 228 (U. S. D. C. N. Y. 1932); Conklin v. Canadian Colonial Airways, Inc., 242 App. Div. 625, 27 I N. Y. S. 1107,1934 U. S. Av. R. $21, a f f^{\prime} d, 266$ N. Y. 244,194 N. E. 692 , r 935 U. S. Av. R. $97 \cdot$

${ }^{17}$ Pennsylvania R. R. v. Hughes, I9I U. S. 477 (rg03); Adams Express Co. v. Croninger, 226 U. S. $49 \mathrm{r}\left(19 \mathrm{I}_{3}\right)$.

${ }^{18}$ Conklin v. Canadian Colonial Airways, Inc., supra note r6; Law v. Transcontinental Air Transport, Inc., I93I U. S. Av. R. 205 (U. S. D. C. E. D. Pa. 193I).

${ }^{10}$ United States v. California, 297 U. S. 175, 181 (1936).

${ }^{20}$ Sec. $403\left(\right.$ a), 52 STAT. 992,49 U. S. C. A. $\$_{4} 83$ (a) (Supp. I948).

${ }^{22}$ Sec. 403 (b), 52 STAT. 992,49 U. S. C. A. $\$ 483$ (b) (Supp. I948).

${ }^{32}$ Sec. 902 (a) and (3), 52 STAT. IOI5, 49 U. S. C. A. $\$ 662$ (a) and (d) (Supp. r948).

${ }^{23}$ Texas and Pacific Ry. v. Mugg and Dryden, 202 U. S. 242 (1906); Louisville and Nashville R. R. v. Maxwell, 237 U. S. 94 (1915); Loomis v. Lehigh Valley R. R., 240 U. S. 43 (I9I6); Lowden v. Simonds-Shields-Lonsdale Grain Co., 306 U. S. 5 I6 (x939). 
contained in a tariff the courts have not been as consistent. ${ }^{24}$ The case of Adams Express Co. v. Croninger 25 is basic in this field. Here the shipper delivered a diamond ring to the express company for interstate shipment. Upon non-delivery of the ring he instituted action for its market value. The defense of the express company was that provisions in the receipt and the tariff filed with the Interstate Commerce Commission required the value of the property shipped to be declared and limited liability for loss to $\$ 50$ if the value was not declared. The Supreme Court held the contracts for shipments of interstate goods were governed by the Interstate Commerce Act and that the shipper was presumed to have knowledge of the filed tariff provisions and was therefore bound by those provisions. The Court based its decision on the Carmack amendment to the Interstate Commerce Act. This decision was followed by several cases ${ }^{26}$ which in turn were followed by the First $^{2 \pi}$ and Second Cummins Amendments to the same Act. ${ }^{28}$ The latter now provides as follows:

Any common carrier, railroad, or transportation company subject to the provisions of this chapter receiving property ... shall issue a receipt or bill of lading therefor, and shall be liable to the lawful holder thereof for any loss, damage, or injury to such property caused by it or by any common carrier, railroad, or transportation company ... and no contract receipt, rule, regulation, or other limitation of any character whatsoever shall exempt such common carrier . . . from the liability hereby imposed; and any such common carrier . . . shall be liable to the lawful holder of said receipt or bill of lading . . . for the full actual loss, damage or injury to such property ... notwithstanding any limitation of liability or limitation of the amount of recovery or representation or agreement as to value in any such receipt or bill of lading, or in any contract, rule, regulation, or in any tariff filed with the Interstate Commerce Commission; and any such limitation, without respect to the manner or form in which it is sought to be made is declared to be unlawful and void; ... . Provided, however, that the provisions hereof respecting liability for full actual loss, damage, or injury, notwithstanding any limitation of liability . . . and declaring any such limitation to be unlawful and void, shall not apply, first, to baggage carried on passenger trains or boats, or trains or boats carrying passengers; second, to property, except ordinary livestock, received for transportation concerning which the carrier shall have been or shall be expressly authorized or required by order of the Interstate Commerce Commission to establish and maintain rates dependent upon the value declared in writing by the shipper or agreed upon in writing as the released value of the property, in which case such declaration or agreement shall have no other effect than to limit liability and recovery to an amount not exceeding the value so declared or released ... and any tariff schedule which may be filed with the commission pursuant to such order shall contain specific reference thereto and may establish rates varying with the value so declared and agreed upon. ...

${ }_{2 s}$ Judge v. Northern Pacific Ry., I89 Fed. I014 (C. C. D. Ore. I9II).

$2=226$ U. S. 49 I (1913).

${ }^{20}$ Chicago, St. P., M. and O. Ry. v. Latta, 226 U. S. 519 (1913); Missouri, K. and T. Ry. v. Harriman, 227 U. S. 657 (1913); Wells Fargo and Co. v. Neiman-Marcus Co., 227 U. S. 469 (1913); Atchison, T. \& S. F. Ry. v. Robinson, 233 U. S. 173 (1914).

${ }^{27}{ }_{38}$ StAT. Irg6 (1915), 49 U. S. C. A. \$20 (Supp. 1948), which made the carricrs fully liable for loss or damage despite any limitation of liability.

${ }_{23} 39$ STAT. 44 I (1916), 49 U. S. C. A. $\$ 20$ (II) (Supp. 1948). 
It is apparent from the above that the Congress has, by express language, permitted the railroads to establish limitations on their liability.

The Civil Aeronautics Act of 1938 does not contain any language similar to that quoted above. Section $484(a)$ of the Act does, however, provide: ${ }^{29}$

It shall be the duty of every air carrier to provide and furnish interstate and overseas air transportation, as authorized by its certificate ... to establish, observe, and enforce just and reasonable individual and joint rates, fares, and charges, and just and reasonable classifications, rules, regulations, and practices relating to such air transportation. . . .

But it is apparent that the duty to establish "just and reasonable . . . rules, regulations, and practices relating to such air transportation" is not equivalent to an express permission to limit liability.

There have been three decisions on the question of the tariffs filed under the Civil Aeronautics Act. In Jones $v$. Northwest Airlines, Inc., ${ }^{30}$ plaintiff purchased a round trip ticket and informed the airline agent that his time within which to make the trip was limited. He was advised that he would probably have adequate time. The ticket contained the usual provision that it was sold subject to tariff regulations. The flight was cancelled because of weather and plaintiff was told that he could have the next available transportation. He demanded a seat on the next plane and was refused. He then brought suit for breach of contract alleging that the contract of carriage was based on the time element involved and that he was entitled to the next available seat. The court held that the plaintiff purchased his ticket subject to tariff provisions on file with the Civil Aeronautics Board, one of which provided that the carrier could at any time without responsibility make any flight cancellations it deemed advisable, and that therefore there was no breach of contract.

In Adler v. Chicago and Southern Air Lines, Inc., ${ }^{31}$ the plaintiff also sued for damages when the airline cancelled a flight. The airline again defended on the ground that its tariffs provided for cancellation. The court disposed of the plaintiff's contention that the rule was unreasonable by dismissing the complaint on the ground that the Civil Aeronautics Board had exclusive jurisdiction to pass on the lawfulness of the rule.

In the third case, Swivalk v. Pennsylvania-Central Airlines Corp., ${ }^{32}$ which is the only American court decision involving a claim for damages to baggage, plaintiff, an intrastate passenger on an interstate airline, brought an action for damages to her baggage caused by the breaking of a bottle of toilet water wrapped securely in her traveling bag. The bottle broke as a result of the defendant's employee placing

${ }^{20} 52$ STAT. 993 (1938), 49 U. S. C. $\$ 484(a)$ (1946).

${ }^{30} 157$ P. $2 d 728$ (1945).

${ }^{31}{ }_{41}$ F. Supp. 366 (E. D. Mo. 1941 ), 1942 U. S. Av. R. $x 8$.

32 I94I U. S. Av. R. 66 (C. C. Mich. 1940). In England the case of Aslan v. Imperial Airways, Ltd., I75 L. T. 378 (K. B. 1933), holds that a provision in a contract of carriage exempting the air carrier from liability for loss of certain gold bullion is valid so there can be no recovery for loss of the bullion. 
a heavy box on the traveling bag. The defendant, pursuant to its business as an interstate carrier, had filed tariffs and regulations with the Civil Aeronautics Authority and one of these had provided under "Articles not acceptable as baggage" that "Except upon special arrangements made in advance ... liquids ... which are not suitable for transport by aircraft ... will not be accepted as baggage or enclosed in luggage." The plaintiff's ticket had printed on it, "Subject to tariff rules and regulations." The court held that the regulation did not apply, since it was not the intention of the air carrier to so hamper air travel as to bar travelers' toilet cases containing small quantities of liquid toilet articles.

It appears from the problems considered above that the courts will uphold any reasonable limitations on liability imposed by the air cargo carrier. We may further assume that when the problem before the court is one dealing with a rate in a tariff, the tariff will be considered the contract of carriage and conclusive as far as rates are concerned. However, when the court has before it a rule or regulation contained in a tariff, it would appear that the rule or regulation may be attacked on the grounds of being unreasonable, of being beyond the intention of the legislature, and in general of being unlawful. ${ }^{33}$

All kinds of ideas have been advanced with the object of freeing civil aviation from the uncertainties created by the existing legal rules of civil liability. These include compulsory insurance, ${ }^{34}$ uniform state liability legislation, ${ }^{35}$ federal liability legislation, ${ }^{36}$ international conventions, ${ }^{37}$ and the formation of mutual cooperative associations by air transport companies to standardize the liabilities of these companies. ${ }^{35}$ This subject has been given most thorough consideration by the American Bar Association, ${ }^{39}$ state aviation officials, ${ }^{40}$ the Air Transport Association, the National Conference of Commissioners on Uniform States Laws, ${ }^{41}$ and the Civil Aeronautics Board. ${ }^{42}$ In order to have any fair workable solution to these uncer-

${ }^{33}$ For two excellent discussions of the entire tariff problem, see Markham and Blair, The Effect of Tariff Provisions Filed Under the Civil Aeronattics Act, 15 J. Arr L. AND Com. 251 (1948), and King, The Effects of Tariff Provisions: Some Further Observations, 16 J. AIr L. AND CoM. 174 (1949).

${ }^{34}$ Ball, Compulsory Airplane Insturance, 4 J. AlR L. 52 (1933); O'Ryan, Limitation of Aircraft Liability, 3 AIR L. REv. 27 (1932).

${ }_{35}$ Knauth, The Uniform State Aeronautical Liability Act, 9 ArR L. Rev. 352 (1938). In opposition to this proposed Act, see David, The Uniform State Aeronautical Code, 8 AnR L. Rev. 282 (1937), and David, Comments on the Proposed Uniform Aviation Liability Act, 9 AIR L. Rev. 359 (I938). Also sce the very careful analysis of the proposed uniform law in Godehn et al., Proposed Law of Air Freight, 8 J. Air. L. 505 (1937), 9 J. Air L. I32 (1938).

${ }^{3 a}$ Sweeney, Report to the Civil Aeronautics Bonrd of a Study of Proposed Aviation Linilutty Legislation (r94I); Fike, The Problem of Interstate Air Commerce Casualties, 9 Arr L. Rev. 250 (1938); Buhler, Limitation of Air Carriers Tort Liability and Related Insurance Coverage-A Proposed Federal Air Passenger Liability Act, II AIR L. Rev. 262 (1940). See H. R. 531, H. R. 532, H. R. 4912, and S. 1905, 79th Congress (1945-1946).

${ }^{37}$ RhyNe, op. cit. supra note 1o, at 252-283.

${ }^{38}$ Fike, Air Transportation Protection, 8 Air L. Rev. 316 (1937).

${ }^{39}$ Report of the Standing Committee on Aeronautical Law, 67 A. B. A. REP. 186 (1942), and Cunrent Status of Aviation Law, a Report to the House of Delegates of the American Ban Association by the Standing Committee on Aeronautical. Law (1947).

- ${ }^{10}$ Report on the Proposed Uniform Aeronautical Code, 9 J. Alr L. 679 (1938).

11 Schnader, Uniform Aviation Liability Act, 9 J. Alr. L. 664 (1938).

${ }^{12}$ See Sweeney, op. cit. supra note 36 . 
tainties it is clear that the air cargo carrier and air cargo shipper must both make reasonable concessions. Also, the insurance industry should contribute its maximum effort in this field of aviation.

The latest survey on aviation insurance was made by the Civil Aeronautics Board in $1944{ }^{43}$ when it was discovered that three insurance groups dominate the American aviation insurance market: Aero Insurance Underwriters, Associated Aviation Underwriters, and United States Aviation Underwriters, Inc. Through them, the group plan of underwriting has been the manner in which aviation insurance has developed in the United States, with a spreading of a given risk over a number of companies. According to the survey the underwriting groups consisted of a small percentage only of the available insurance companies in the United States, ${ }^{44}$ but they were providing a wide range of coverage which at this time did not include writing insurance on cargo. However, the groups expressed the desire to go into this field in the future. On the basis of information furnished the Board it concluded that underwriting experience in the field of aviation had been favorable, with substantial profits. ${ }^{45}$ The Board further found an absence of competition among the underwriters but did not find any agreements between them or that one group dominated another. The Board concluded that there was no question but that in America there were adequate insurance assets for the aviation market and that the Federal Government had an interest in seeing that the American aviation insurance market functioned so as to make its maximum contributions to the development and expansion of aviation. The Board remarked on the unavailability and inadequacy of information furnished, and stated that the information before it did not permit any conclusions as to whether the aviation market had been functioning in accord with the public interest in the development of aviation. The Board concluded the report by stating continued observation was in order, but unfortunately as of the writing of this article nothing further has apparently been done. It is certainly true, as the Board concludes, that at least as of the date of the report there were substantial insurance resources not participating in the field of aviation and that the American insurance market could contribute much in this field.

In considering a reasonable solution to the problems presented it is interesting to look at other types of common carriers of cargo and see how their problems have been dealt with.

In the very closely related field of international transportation of cargo by air the Warsaw Convention ${ }^{46}$ is controlling. The United States and most of the major

${ }^{13}$ Civir Aeronautics Bonsd, A Study of Aviation Insurance (1944).

"During the year 1942 there were 267 American stock fire insurance companies doing business in the United States and only 76 were members of the three groups; also there were 181 stock casualty insurance companies and 23 were members of the three groups. See Shrimpton, Insurance on Wings, I7 RockY Mit. L. Rev. 58 (1944).

${ }^{5}$ During the year $194 \mathrm{I}$ the three underwriting groups wrote $\$ 13,303,034$ worth of premiums for all classes of aviation risks. Profits amounted to 25.4 per cent of premiums for airline insurance alone and 25.9 per cent of premiums when all classes of aviation insurance were considered.

${ }_{10}^{49}$ STAT. 3000 (1934), International Air Transportation, U. S. TrEATY SER. No. 876 (1934). 
nations of the world are parties to this. The Convention applies to all international transportation of persons, baggage or goods performed by aircraft for hire, with no distinction between common and private carriers. ${ }^{47}$ The Convention requires the issuance of a specified passenger ticket, baggage check, and air waybill and gives the detailed provisions which "must" be included. ${ }^{48}$ If an air carrier accepts a passenger, baggage, or goods without issuing the passenger ticket, baggage check, or air waybill, it is not entitled to avail itself of those provisions of the Convention which exclude or limit its liability. ${ }^{49}$ The Convention provides that the air carrier shall be liable for damages sustained by destruction, loss, or damage to baggage or goods, ${ }^{\text {,0 }}$ with the defense available to the carrier that the damage was occasioned by error in piloting, in the handling of the aircraft, or in navigation, and that in all other respects the carrier had taken all necessary measures to avoid damage.51 The Convention provides a limitation for baggage and goods of 250 francs per kilogram, ${ }^{62}$ unless a higher declaration of value was made and a supplementary sum paid. ${ }^{63}$ The liability provisions of the Convention are limitations rather than indemnities and the damage claimed must be justified. Further, the carrier is prohibited from relieving itself of liability or fixing a lower limit than that laid down by the Convention. ${ }^{64}$ The Convention provides that any clause in a contract of transportation and all special agreements entered into before damage occurs by which the parties purport to infringe the rules laid down by the convention are null and void. ${ }^{65}$

In considering the railroad as a common carrier of cargo it has been noted above $e^{60}$ that the railroads' liability as insurers under the common law has been relaxed so as to permit them to establish rates based upon the declared values for baggage and express, thereby validating their liability limitation provisions. The Carmack amendment has been extended to goods shipped by motor vehicles in interstate commerce, ${ }^{5 \tau}$ and the common carrier by water in regard to goods carried may limit its liability but only by the stipulation of value in the bill of lading. ${ }^{58}$

One of the ideas advanced with the object of freeing civil aviation from the uncertainties created by existing rules of civil liability is the Uniform Aviation Liability Act, ${ }^{59}$ which if adopted by any state would apply to aircraft flying within the state. In the case of passengers and goods it would apply when the contract of carriage is made within the state. Under this uniform law absolute liability would be imposed

${ }^{47}$ Id. Art. I.

${ }^{28}$ Id. Arts. 3-16.

"Ibid.

${ }^{50} 1 d$. Art. 18.

${ }^{31}$ Id. Art. 20(2).

62 This amounts to approximately $\$ 16.58$ per kilogram in U. S. currency.

${ }^{63}$ U. S. TReATY SER. No. 876 , op. cit. supra note 46 , Art. $22(2)$.

Id. Art. 23.

${ }^{6} \mathrm{Id}$. Art. 32. For an article stating that the Warsaw Convention is unfair to the air cargo shipper, see Wolf, The Unwary Airshipper's Peril, 20 PA. BAR Ass's Q. (1949).

${ }^{50}$ Supra note 28.

${ }^{57}$ Sec. 129, Motor Carrier Act, 49 STAT. 563 (1935), 49 U. S. C. A. \$319 (Supp. 1948).

${ }^{58}$ Harter Act, 27 STAт. 445 (1893), 46 U. S. C. A. \$\$190-195 (Supp. I948).

"Stupra note 35 . 
for loss or damage to goods, but if the value of the goods or baggage is not declared the recovery is limited to $\$$ Ioo. Another idea advanced is federal liability legislation, ${ }^{60}$ with the carrier having the necessity of proving non-negligence in the case of loss or damage to goods.

It is evident that there are uncertainties in the field of air cargo transportation. It is likewise evident that in every other field of cargo transportation there is uniformity. In international air cargo transportation there is the Warsaw Convention. In cargo transportation by railroad and motor carrier there is the Carmack Amendment, and in transportation of cargo by water there is the Harter Amendment. A uniform law is essential, and in view of the difficulty involved in having the various states adopt a uniform law, federal legislation is needed to settle in a uniform manner the liability questions which can arise in connection with the carriage by air of baggage and express under existing law.

${ }^{\circ 0}$ Supra note 36. 